\title{
An Efficient Synthesis of Enantiomerically Pure $\gamma$-Aminobutyric Acid (GABA) Derivatives
}

\author{
Huixia Liu, Jiani Yuan, Qinqin Tian, Nan Ji, Wei He* \\ Department of Chemistry, School of Pharmacy, Fourth Military Medical University, Xi'an, China \\ Email: *weihechem@fmmu.edu.cn
}

How to cite this paper: Liu, H.X., Yuan, J.N., Tian, Q.Q., Ji, N. and He, W. (2017) An Efficient Synthesis of Enantiomerically Pure $\gamma$-Aminobutyric Acid (GABA) Derivatives. Journal of Materials Science and Chemical Engineering, 5, 25-32.

https://doi.org/10.4236/msce.2017.58003

Received: July 14, 2017

Accepted: August 8, 2017

Published: August 11, 2017

\begin{abstract}
Chiral $\gamma$-aminobutyric acid (GABA) derivatives are the normal inhibitory neurotransmitters in the mammalian central nervous system. In this paper, enantiopure GABA derivatives 6 were synthesized via reduction/cyclization/hydrolysis cascade reactions from the highly enantioselective $\beta$-aryl- $\gamma$ nitroalkanes Michael adducts 4, which was obtained from asymmetric Michael addition of $S, S$-diphenyldithiomalonate 2 to trans- $\beta$-nitroolefins 1 , using novel chiral cinchona alkaloid-derived thioureas 3 as the organocatalysts. This synthesis represents an efficient, highly selective and environmental benign methodology for GABA derivatives
\end{abstract}

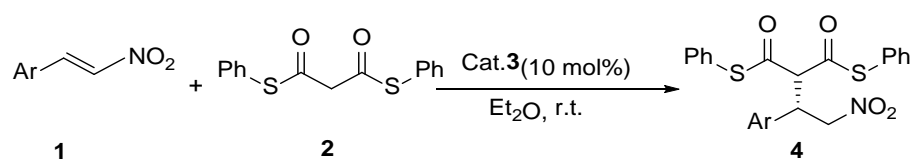

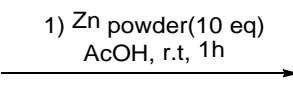

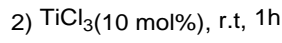

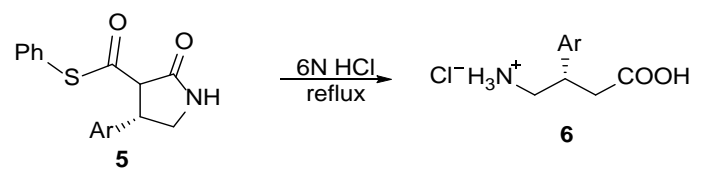

\section{Keywords}

Chiral, GABA, Organocatalyst, Asymmetric Michael Addition

\section{Introduction}

GABA is the most common inhibitory neurotransmitters in the mammalian central nervous system (CNS) where it exerts its effects through inhibiting GABA receptors channels. And decreased GABA biological activity results in the excessive excitement of CNS (namely Neuronal Firing). The dysfunction of the 
central GABA system is responsible for the development and outbreak of epilepsy [1], Huntington's, Parkinson's diseases [2] and other psychiatric disorders, such as anxiety and pain [3]. Various GABA derivatives and analogs are widely recognized as CNS depressants, for example: Phenibut, Baclofen (Lioresal and Baclon $^{\oplus}$ ), Vigabatrin, Gabapentin (GBP, Neurontin), Pregabalin (Lyrica, Pfizer’s blockbuster drug, $\beta$ - $i$-Bu-GABA) (Figure 1).

Enantiomers of a drug are often known to play an important role in pharmacological actions, pharmacokinetics, toxicities and metabolism. The biological activity of some drugs depends on their absolute configuration. Therefore, the use of a single isomer of a given drug is usually recommended for clinical use [4]. It has reported that $(R)$-enantiomer of GABA derivatives is much more active than $(S)$-enantiomer [5] [6] [7]. For example, in pharmacological tests of locomotor activity, antidepressant and pain effects, $(S)$-phenibut was inactive in doses up to $500 \mathrm{mg} / \mathrm{kg}$, but in contrast, $(R)$-phenibut turned out to be two times more potent than racemic phenibut in most of the tests. In the forced swimming test, at a dose of $100 \mathrm{mg} / \mathrm{kg}$ only $(R)$-phenibut significantly decreased immobility time. Consequently, obtaining enantiomerically pure GABA derivatives as a new modulators has become one of the most effective approaches for the development of extracellular GABA homeostasis in the CNS.

In this paper, we report the asymmetric Michael addition of $S$, $S$-diphenyldithiomalonate 2 to trans- $\beta$-nitroolefins 1 , catalyzed by chiral cinchona alkaloid-derived thioureas organocatalysts 3 , to give a series of corresponding chiral $\beta$-aryl- $\gamma$-nitroalkanes 4 in moderate to good yields, along with excellent stereoselectivities. And their transformations into biologically attractive chiral GABA derivatives 6 via reduction/cyclization/hydrolysis cascade reactions were reported.

\section{Experimental}

\subsection{Materials}

Trans $-\beta$-nitroolefins, benzotrifluoride, $\mathrm{TiCl}_{3}$ were purchased from commercial

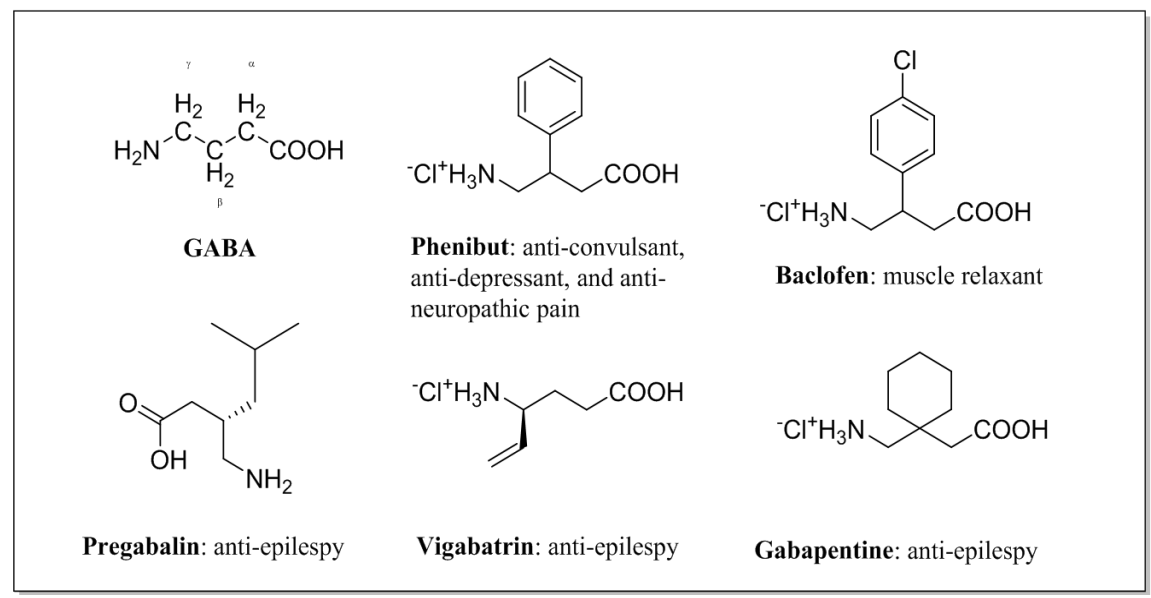

Figure 1. GABA and its analogs used as CNS depressants. 
suppliers and were used without further purification. $S$, $S$-diphenyldithiomalonate $\mathbf{2}$ and cinchona alkaloid-derived thioureas $\mathbf{3}$ were previously synthesized in our laboratory. Zinc powder was freshly activated before usage. DCM and toluene were freshly distilled before usage. Analytical thin layer chromatography (TLC) was performed on Kiselgel $60 \mathrm{~F}_{254}$ plates. ${ }^{1} \mathrm{H}$ NMR or ${ }^{13} \mathrm{C}$ NMR spectra were recorded in $\mathrm{CDCl}_{3}$ and $\mathrm{CD}_{3} \mathrm{OD}$, and the solvent signals (7.26/77.0 and 3.31/ $49.0 \mathrm{ppm}$ ) were used as reference. The yields are isolated by column chromatographygel plates. Percent enantiomeric excess (ee \%) was determined by Agilent 1260 interfaced to a HP 71 series computer workstation with Chiralpak OD-H column. Optical rotations were determined on a polarimeter at $589 \mathrm{~nm}$. Melting points were determined by using a XRC-1 microferrometer and are uncorrected. Specific rotations were measured in a Perkin-Elmer 343 polarimeter at room temperature and $\lambda=589 \mathrm{~nm}$. The purification of all compounds was carried out by column chromatography using (silica gel 200 - 300).

\subsection{Synthesis of $\beta$-Aryl- $\gamma$-Nitroalkanes 4 Vis Asymmetric Michael Addition}

For the synthesis of the important intermediates $\beta$-aryl- $\gamma$-nitroalkanes 4, asymmetric Michael addition was studied. We initially examined two kinds of cinchona alkaloid-derived bifunctional thioureas $\mathbf{3 a - b}$ as potential organocatalysts for the asymmetric Michael addition of $S, S$-diphenyldithiomalonate 2 to trans- $\beta$-nitroolefins 1 in benzotrifuoride at room temperature, leading to the expected $\gamma$-nitroalkanes derivative 4 in good yield and excellent stereoselectivity (Table 1). Quinidine-derived thiourea $3 b$, pseudoenantiomer of $3 a$, effectively catalyzed the reaction and gave $\mathbf{4 a}, \mathbf{4 b}$ and $\mathbf{4 c}$ with opposite absolute configuration in similar enantioselectivities (Table 1, entries 2, 4, 6 vs 1, 3, 5). Upon screening the various solvents, we found that benzotrifluoride produced better results than any other polar or less polar solvents, such as DCM, diethyl ether, touene and methanol.

Thus, the best reaction conditions was obtained when carrying out the reaction with 1.0 equiv of trans- $\beta$-nitroolefins 1 and 1.0 equiv of $S, S$-diphenyldithiomalonate 2 in benzotrifluoride $(1 \mathrm{~mL})$ at room tempreature in the presence of $10 \% \mathrm{~mol}$ of $3 \mathrm{a} / \mathrm{b}$ as catalysts for $12 \mathrm{~h}$ (Table 1 ).

General experiment procedure: To the solution of trans- $\beta$-nitroolefins 1 (0.1 $\mathrm{mmol})$ and $S, S$-diphenyldithiomalonate $2(0.1 \mathrm{mmol})$ in benzotrifluoride $(1.0$ $\mathrm{m} \mathrm{L}$ ) was added $3(4.52 \mathrm{mg}, 0.01 \mathrm{mmol})$. The resulting mixture was stirred at room temperature for $12 \mathrm{~h}$ until the reaction completed (monitored by TLC). After filtration, the products were furnished.

(S)-2-(2-Nitro-1-phenylethyl)-malonic acid diphenyl dithioester (4a). White solid; yield 92\%; 96\% ee, ${ }^{1} \mathrm{H}$ NMR (400 $\left.\mathrm{MHz}, \mathrm{CDCl}_{3}\right): \delta 7.47-7.41(\mathrm{~m}, 5 \mathrm{H}), 7.39$ - $7.33(\mathrm{~m}, 6 \mathrm{H}), 7.28-7.26(\mathrm{~m}, 2 \mathrm{H}), 7.14(\mathrm{dd}, J=7.60 \mathrm{~Hz}, J=1.60 \mathrm{~Hz}, 2 \mathrm{H}), 4.88$ $4.82(\mathrm{~m}, 2 \mathrm{H}), 4.48(\mathrm{~d}, J=8.80 \mathrm{~Hz}, 1 \mathrm{H}), 4.42-4.36(\mathrm{~m}, 1 \mathrm{H}) \mathrm{ppm} ; \mathrm{IR}(\mathrm{KBr}): v 1697$, 1670, 1558, 1473, 1438, 1377, 1261, 1022, 964, 798, 748, $686 \mathrm{~cm}^{-1}$; HPLC: 
Table 1. The Asymmetric Michael Addition Reaction of $S, S$ 'diphenyldithiomalonate 2 to trans- $\beta$-nitroolefins 1 .

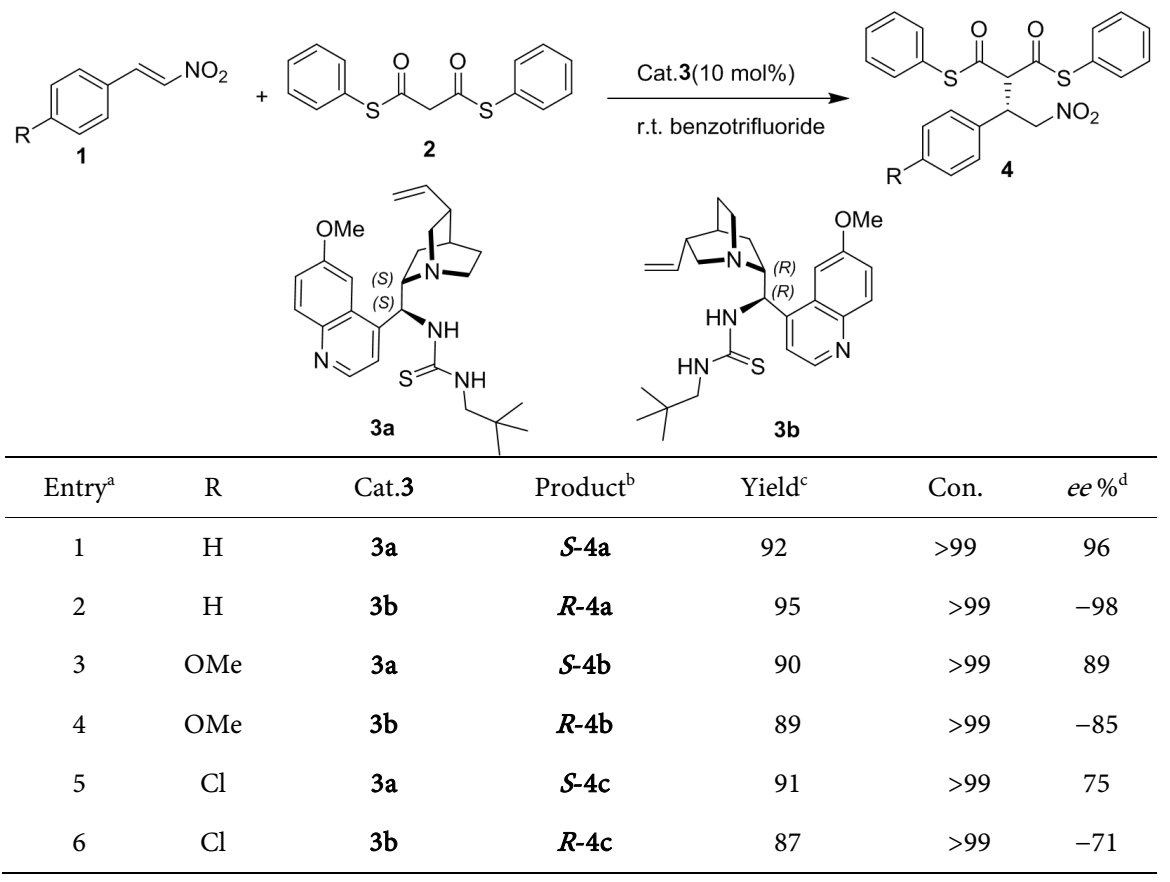

a. Unless otherwise noted, reaction was carried out with $S, S$-diphenyldithiomalonate $2(0.1 \mathrm{mmol})$ to trans- $\beta$-nitroolefins $1 \mathrm{c}(0.1 \mathrm{mmol})$ and catalyst $3(0.01 \mathrm{mmol})$ in $1 \mathrm{~mL}$ solvent. b. Absolute configuration was determined by comparison with available literature HPLC data [8] [9]. c.Isolated yields. d. Percent enantiomeric excess (ee\%) was determined by chiral HPLC analysis (Chiralpak OD-H).

Chiralcel OD-H column, Hex/i-PrOH 70:30, $1.0 \mathrm{~mL} / \mathrm{min}$, t: major $15.6 \mathrm{~min}$; $\mathrm{t}$ minor: 19.7 min.

(R)-2-(2-Nitro-1-phenylethyl)-malonic acid diphenyl dithioester (4a).White solid; yield 95\%; 98\% ee, ${ }^{1} \mathrm{H}$ NMR and IR date are identical to (S)-4a; HPLC: Chiralcel OD-H column, Hex/ $i-\mathrm{PrOH}$ 70:30, $1.0 \mathrm{~mL} / \mathrm{min}$, t major: 21.9 min; t: minor $19.0 \mathrm{~min}$.

(S)-2-(1-(4-Methoxy-phenyl)-2-nitro-ethyl)-malonic acid diphenyl dithioester (4b). White solid; yield 90\%; 89\% ee, ${ }^{1} \mathrm{H} \mathrm{NMR}\left(\mathrm{CDCl}_{3}, 400 \mathrm{MHz}\right): \delta 7.43-$ 7.35(m, 9H), 7.19-7.16(m, $4 \mathrm{H}), 6.87(\mathrm{~d}, J=8.8 \mathrm{~Hz}, 2 \mathrm{H}), 4.81-4.79(\mathrm{~m}, 2 \mathrm{H})$, $4.45(\mathrm{~d}, J=9.6 \mathrm{~Hz}, 1 \mathrm{H}), 4.38-4.32(\mathrm{~m}, 1 \mathrm{H}), 3.79(\mathrm{~s}, 3 \mathrm{H}) \mathrm{ppm}$; IR(KBr): $v$ 1701, $1558,1550,1515,1477,1438,1377,1253,1180,1026,964,833,748,686 \mathrm{~cm}^{-1}$; HPLC: Chiralcel OD-H column, Hex/i-PrOH 70:30, $1.0 \mathrm{~mL} / \mathrm{min}, \mathrm{t}$ major: 18.2 min; t minor: $26.1 \mathrm{~min}$.

(R)-2-(1-(4-Methoxy-phenyl)-2-nitro-ethyl)-malonic acid diphenyl dithioester (4b). White solid; yield 89\%; 85\% ee, ${ }^{1} \mathrm{H}$ NMR and IR date are identical to (S)-5a; HPLC: Chiralcel OD-H column, Hex/i-PrOH 70:30, $1.0 \mathrm{~mL} / \mathrm{min}$, t major: 26.7 min; t minor: 18.4 min.

(S)-2-(1-(4- Chloro-phenyl)-2-nitro-ethyl)-malonic acid diphenyl dithioester (4c). White solid; yield: $91 \%$; $75 \%$ ee; $\mathrm{mp}: 122^{\circ} \mathrm{C}-123^{\circ} \mathrm{C},[\alpha]_{\mathrm{D}}{ }^{25}=+77.6(c=$ $\left.0.25, \mathrm{CHCl}_{3}\right) ;{ }^{1} \mathrm{H}$ NMR $\left(400 \mathrm{MHz}, \mathrm{CDCl}_{3}\right): \delta 7.48-7.45(\mathrm{~m}, 3 \mathrm{H}), 7.44-7.41(\mathrm{~m}$, $3 \mathrm{H}), 7.40-7.38(\mathrm{~m}, 2 \mathrm{H}), 7.35(\mathrm{~d}, J=8.40 \mathrm{~Hz}, 2 \mathrm{H}), 7.22(\mathrm{~d}, J=8.40 \mathrm{~Hz}, 2 \mathrm{H}), 7.18$ 
$(\mathrm{dd}, J=7.60 \mathrm{~Hz}, J=1.20 \mathrm{~Hz}, 2 \mathrm{H}), 4.81(\mathrm{~d}, J=5.60 \mathrm{~Hz}, 2 \mathrm{H0}, 4.44(\mathrm{~d}, J=9.60 \mathrm{~Hz}$, $1 \mathrm{H}), 4.40-4.35(\mathrm{~m}, 1 \mathrm{H}) \mathrm{ppm} ;{ }^{13} \mathrm{C} \mathrm{NMR}\left(100 \mathrm{MHz}, \mathrm{CDCl}_{3}\right): \delta 189.97,189.15$, $134.36,133.97,133.90,133.47,130.06,129.92,129.44,129.32,129.20,129.06$, $125.60,125.54,68.76,43.36 \mathrm{ppm}$; IR(KBr): $v 1701,1558,1550,1477,1438,1388$, 1261, 1095, 1014, 960, 910, 829, 748, 686, $543 \mathrm{~cm}^{-1}$; HRMS-ESI $(\mathrm{m} / \mathrm{z}):[\mathrm{M}+\mathrm{Na}]^{+}$ calcd for $\mathrm{C}_{24} \mathrm{H}_{18} \mathrm{ClNNaO}_{4} \mathrm{~S}_{2}$ 494.0258, found 494.0257; HPLC: Chiralcel OD-H column, Hex/i-PrOH 70:30, $1.0 \mathrm{~mL} / \mathrm{min}$, $\mathrm{t}$ major: $19.3 \mathrm{~min}$; $\mathrm{t}$ minor: $30.1 \mathrm{~min}$.

(R)-2-(1-(4-Chloro-phenyl)-2-nitro-ethyl)-malonic acid diphenyl dithioester (4c). Dark green solid; yield: $91 \%$; $75 \%$ ee; mp: $122^{\circ} \mathrm{C}-123^{\circ} \mathrm{C},[\alpha]_{\mathrm{D}}{ }^{25}=+77.6(\mathrm{c}$ $\left.=0.25, \mathrm{CHCl}_{3}\right) ;{ }^{1} \mathrm{H} \mathrm{NMR},{ }^{13} \mathrm{C} \mathrm{NMR}$, IR and HRMS-ESI date are identical to

(S)-4c; HPLC: Chiralcel OD-H column, Hex/i-PrOH 70:30, $1.0 \mathrm{~mL} / \mathrm{min}$, t major: $24.1 \mathrm{~min}$; $\mathrm{t}$ minor: $15.9 \mathrm{~min}$.

\subsection{Synthesis of $(S) /(R)-\beta$-Phenyl- $\gamma$-Lactam 5 a}

Considering that $\beta$-aryl- $\gamma$-nitroalkanes derivatives 4 are potential drug candidates, the transformation of adduct $4 \mathrm{a}$ to $5 \mathrm{a}$ was investigated as illustrated in Scheme 1 . When adduct $(S)-4 a(96 \%$ ee) was treated with zinc/acetic acid and $\mathrm{TiCl}_{3}$, nitro group transformed into the amine and followed by intramolecular cyclization to produce the $(S)$ - $\beta$-phenyl- $\gamma$-lactam $5 \mathbf{a}$ in good yield $(90 \%)$ and only a few influence of enantioselectivity ( $91 \%$ ee) via subsequent reduction/ cyclization cascade reactions in a one-pot sequential protocol [10]. Under identical conditions, the adduct $(R)-4$ a $(98 \%$ ee) was transformed into $(R)$ - $\beta$-phenyl$\gamma$-lactam $5 \mathrm{a}$ in $90 \%$ yield and $89 \%$ ee (Scheme 1 ).

General procedure: To the solution of adduct $4 \mathrm{a}(218 \mathrm{mg}, 0.5 \mathrm{mmol}, 1.0$ equiv) in $\mathrm{AcOH}(5.0 \mathrm{~mL})$ was added freshly activated zinc powder (330 mg, 5 mmol, 10 equiv) and the resulting solution was stirred at $25^{\circ} \mathrm{C}$ under a nitrogen atmosphere for $1 \mathrm{~h}$. After this period, $\mathrm{TiCl}_{3}(6.5 \mu \mathrm{L}, 0.05 \mathrm{mmol}, 0.1$ equiv) was added and stirred for additional $1 \mathrm{~h}$ until the reaction completed (monitored by<smiles>O=C(Sc1ccccc1)C([C](Cl)c1ccccc1)C(=O)Sc1ccccc1</smiles>

(S)-4a

$96 \% e e$<smiles>O=C(Sc1ccccc1)C(C(=O)Sc1ccccc1)[C@H](C[N+](=O)[O-])c1ccccc1</smiles>

(R)-4a

98\% eе

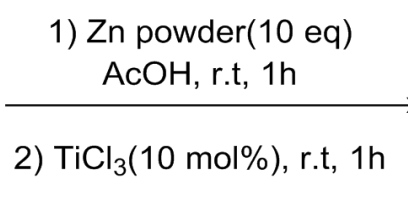

yield:90\%

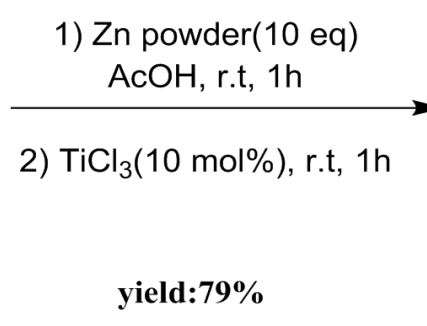<smiles>O=C1NCC(=[Se])C1C(=O)Sc1ccccc1</smiles>

(S)-5a

$91 \%$ ee<smiles>O=C1NC[C@H](c2ccccc2)C1C(=O)Sc1ccccc1</smiles>

(R)-5a

89\% ee

Scheme 1. Preparation of $\beta$-phenyl- $\gamma$-lactam 5 a. 
TLC). The crude material was filtered, concentrated and purified by silicagel chromatography (petroleum ether/ethyl acetate $=10: 1, \mathrm{v} / \mathrm{v}$ ) to give the $5 \mathrm{a}$ as a white solid.

(S)-phenyl (4S)-2-oxo-4-phenylpyrrolidine-3-carbothioate (5a). White solid; mp: $160^{\circ} \mathrm{C}-162^{\circ} \mathrm{C}$; yield 90\%; 91\% ee; $[\alpha]_{\mathrm{D}}{ }^{25}=+180\left(c=0.25, \mathrm{CHCl}_{3}\right) ;{ }^{1} \mathrm{H}$ NMR $\left(400 \mathrm{MHz}, \mathrm{CDCl}_{3}\right): \delta 8.30-8.20(\mathrm{~s}, 1 \mathrm{H}), 7.55-7.25(\mathrm{~m}, 10 \mathrm{H}), 4.88-4.82(\mathrm{~m}, 2 \mathrm{H})$, $4.48(\mathrm{~d}, J=8.80 \mathrm{~Hz}, 1 \mathrm{H}), 4.42-4.36(\mathrm{~m}, 1 \mathrm{H}) \mathrm{ppm}$; IR $(\mathrm{KBr}): v 3217,3062,2924$, 2854, 1716, 1693, 1496, 1477, 1454, 1438, 1261, 1053, 1026, 1007, 821, $752 \mathrm{~cm}^{-1}$; HPLC: Chiralcel OD-H column, Hex/i-PrOH 70:30, $1.0 \mathrm{~mL} / \mathrm{min}, \mathrm{t}$ major: 23.0 min; t minor: 19.4 min.

(S)-phenyl (4R)-2-oxo-4-phenylpyrrolidine-3-carbothioate (5a). White solid; mp: $160^{\circ} \mathrm{C}-162^{\circ} \mathrm{C}$; yield $79 \% ; 89 \% e e ;[\alpha]_{\mathrm{D}}{ }^{25}=+210\left(c=0.25, \mathrm{CHCl}_{3}\right) ;{ }^{1} \mathrm{H} \mathrm{NMR}$ and IR date are identical to (S)-5a; HPLC: Chiralcel OD-H column, Hex/i-PrOH 70:30, $1.0 \mathrm{~mL} / \mathrm{min}$, $\mathrm{t}$ major: $14.6 \mathrm{~min}$; minor: $18.8 \mathrm{~min}$.

\subsection{Synthesis of $(S) /(R)$-Phenibut}

Phenibut is a therapeutically useful agonist of GABA type-B receptors and is used as a neuropsychotropic drug [11] [12]. To get the enantiomerically pure Phenibut, a tandem hydrolysis-decarboxylation reaction of the $\beta$-phenyl- $\gamma$-lac$\operatorname{tam}(S)$-5a with $6 \mathrm{~N} \mathrm{HCl}$ was carried out, producing the $(S)$-Phenibut hydrochloride $6 \mathrm{a}$ in $85 \%$ yield. The absolute stereochemistry of $6 \mathrm{a}$ was confirmed by the comparison of the optical rotation data and chiral HPLC spectrum of $5 \mathrm{a}$ with reported data [11] [12]. Under identical conditions, the $\beta$-phenyl- $\gamma$-lactam $(R)$ $\mathbf{5 a}$ was transformed into $(R)$-Phenibut hydrochloride $\mathbf{6 a}$ in $81 \%$ yield (Scheme 2 ).

General procedure: The $S$ - $\beta$-phenyl- $\gamma$-lactam $5 \mathrm{a}(96 \mathrm{mg}, 0.32 \mathrm{mmol})$ and $6 \mathrm{~N}$ $\mathrm{HCl}(5 \mathrm{~mL})$ was refluxed for $3.5 \mathrm{~h}$. After cooling, the reaction mixture was washed with DCM. The components in water phase were concentrated in vacuum under reduced pressure to afford $(S)$-Phenibut $6 \mathrm{a}$ in $\mathrm{HCl}$ salt form as a white solid.<smiles>O=C1NCC(c2ccccc2)C1C(=O)Sc1ccccc1</smiles>

$(S)-5 \mathbf{a}$<smiles>O=C1NCC(c2ccccc2)C1C(=O)Sc1ccccc1</smiles>

$(R)-5 a$

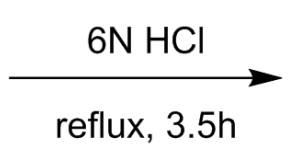

yield: $\mathbf{8 5} \%$

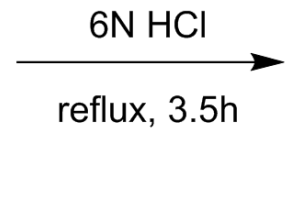

yield: $81 \%$<smiles>[NH3+]C[C@H](CC(=O)O)c1ccccc1</smiles>

(S)-6a<smiles>[NH3+]C[C@H](CC(=O)O)c1ccccc1</smiles>

$(R)-6 a$

Scheme 3. Preparation of $(S) /(R)$-Phenibut hydrochloride 6a. 
(S)-4-amino-3-phenylbutanoic acid hydrochloride (6a). White solid; yield: 85\%; mp: $194^{\circ} \mathrm{C}-195^{\circ} \mathrm{C},[\alpha]_{\mathrm{D}}{ }^{25}=+6.1\left(c=0.25, \mathrm{H}_{2} \mathrm{O}\right) ;{ }^{1} \mathrm{H}$ NMR, $(400 \mathrm{MHz}$, $\left.\mathrm{CD}_{4} \mathrm{O}\right) \delta: 7.43(\mathrm{~d}, 2 \mathrm{H}), 7.37(\mathrm{~m}, 3 \mathrm{H}), 3.40(\mathrm{~m}, 2 \mathrm{H}), 3.25(\mathrm{q}, 1 \mathrm{H}), 2.84(\mathrm{dd}, J=5.5$ $\mathrm{Hz}, J=16.1,2 \mathrm{H}), 2.75(\mathrm{dd}, J=5.5, J=9.8 \mathrm{~Hz}, 2 \mathrm{H}) \mathrm{ppm}$. IR $(\mathrm{KBr}): v 1700,1552$, $1441,1381,981,751,657,639 \mathrm{~cm}^{-1}$;

(R)-4-amino-3-phenylbutanoic acid hydrochloride (6a). White solid; yield: 81\%; mp: $194^{\circ} \mathrm{C}-195^{\circ} \mathrm{C} ;[\alpha]_{\mathrm{D}}{ }^{25}=-5.0\left(c=0.25, \mathrm{H}_{2} \mathrm{O}\right) ;{ }^{1} \mathrm{H}$ NMR and IR date are identical to $(S)-6 a$.

\section{Conclusion}

In conclusion, we have developed the first example of cinchona alkaloid-derived thioureas-catalyzed asymmetric Michael addition of $S$, $S$-diphenyldithiomalonate to trans- $\beta$-nitroolefins. An efficient asymmetric synthesis of biologically attractive chiral GABA derivatives $(S)$ or $(R)$-Phenibut was readily accomplished by reduction/cyclization/ hydrolysis sequential reactions. Easily obtained substrates, catalysts and a simple experimental procedure constitute peculiar advantages of this method. Investigations aimed at developing more effective transformation of $\beta$-aryl- $\gamma$-nitroalkanes adducts to GABA derivatives without any effect on enantioselectivities are currently ongoing in our laboratory.

\section{Acknowledgements}

The financial support of National Major Scientific and Technological Special Project for "Significant New Drugs Development" (No. 2014ZX09J14104-06C) and the Young Scholar Foundation of the Fourth Military Medical University are gratefully acknowledged.

\section{References}

[1] Andersen, K.E., Braestrup, C., Gronwald, F.C., Jorgensen, A.S., Nielsen, E.B., Sonnewald, U., Knutsen, L.J., et al. (1993) The Synthesis of Novel GABA Uptake Inhibitors. 1. Elucidation of the Structure-Activity Studies Leading to the Choice of (R)-1-[4,4-bis(3-methyl-2-thienyl)-3-butenyl]-3-piperidinecarboxylic Acid (Tiagabine) as an Anticonvulsant Drug Candidate. Journal of medicinal chemistry, 3612, 1716-1725. https://doi.org/10.1021/jm00064a005

[2] Krogsgaard-Larsen, P., Krogsgaard-Larsen, P., Arnt, J. and Arnt, J. (1979) GABA Receptor Agonists: Relationship between Structure and Biological Activity in Vivo and in Vitro. Advances in Experimental Medicine and Biology, 123, 303-321. https://doi.org/10.1007/978-1-4899-5199-1_18

[3] Shashoua, V.E., Jacob, J.N., Ridge, R., Campbell, A. and Baldessarini, R.J. (1984) Gamma-Aminobutyric Acid Esters. 1. Synthesis, Brain Uptake, and Pharmacological Studies of Aliphatic and Steroid Esters of Gamma-Aminobutyric Acid. Journal of Medicinal Chemistry, 275, 659-664. https://doi.org/10.1021/jm00371a018

[4] Maier, N.M., Franco, P. and Lindner, W. (2001) Separation of Enantiomers: Needs, Challenges, Perspectives. Journal of Chromatography A, 9061-2, 3-33.

https://doi.org/10.1016/S0021-9673(00)00532-X

[5] Dambrova, M., Zvejniece, L., Liepinsh, E., Cirule, H., Zharkova, O., Veinberg, G. 
and Kalvinsh, I. (2008) Comparative Pharmacological Activity of Optical Isomers of Phenibut. European Journal of Pharmacology, 5831, 128-134.

https://doi.org/10.1016/j.ejphar.2008.01.015

[6] Baures, P.W., Eggleston, D.S., Erhard, K.F., Cieslinski, L.B., Torphy, T.J. and Christensen, S.B. (1993) The Crystal Structure, Absolute Configuration, and Phosphodiesterase Inhibitory Activity of (+)-1-(4-Bromobenzyl)-4-(3-(cyclopentyloxy)4-methoxyphenyl)-pyrrolidin-2-one. Journal of Medicinal Chemistry, 3622, 32743277. https://doi.org/10.1021/jm00074a007

[7] Schneider, H.H., Schmiechen, R., Brezinski, M. and Seidler, J. (1986) Stereospecific Binding of the Antidepressant Rolipram to Brain Protein Structures. European Journal of Pharmacology, 1271-2, 105-115. https://doi.org/10.1016/0014-2999(86)90210-4

[8] Jin, H., Kim, S.T., Hwang, G.S. and Ryu, D.H. (2016) L-Proline Derived Bifunctional Organocatalysts: Enantioselective Michael Addition of Dithiomalonates to TransBeta-Nitroolefins. The Journal of organic chemistry, 818, 3263-3274. https://doi.org/10.1021/acs.joc.6b00218

[9] Wang, J., Li, W., Liu, Y., Chu, Y., Lin, L., Liu, X. and Feng, X. (2010) Asymmetric Cyanation of Activated Olefins with Ethyl Cyanoformate Catalyzed by a Modular Titanium Catalyst. Organic Letters, 126, 1280-1283. https://doi.org/10.1021/ol100169r

[10] Kolarovic, A., Kaslin, A. and Wennemers, H. (2014) Stereoselective Synthesis of Indolines via Organocatalytic Thioester Enolate Addition Reactions. Organic Letters, 1616, 4236-4239. https://doi.org/10.1021/ol501936n

[11] Lapin I. (2001) Phenibut (Beta-Phenyl-GABA): A Tranquilizer and Nootropic Drug. CNS Drug Reviews, 74, 471-481.

[12] Zvejniece, L., Vavers, E., Svalbe, B., Veinberg, G., Rizhanova, K., Liepins, V., Kalvinsh, I. and Dambrova, M. (2015) R-Phenibut Binds to the $\alpha_{2}-\delta$ Subunit of VoltageDependent Calcium Channels and Exerts Gabapentin-Like Anti-Nociceptive Effects. Pharmacology, Biochemistry, and Behavior, 137, 23-29. https://doi.org/10.1016/j.pbb.2015.07.014

\section{Submit or recommend next manuscript to SCIRP and we will provide best} service for you:

Accepting pre-submission inquiries through Email, Facebook, LinkedIn, Twitter, etc. A wide selection of journals (inclusive of 9 subjects, more than 200 journals)

Providing 24-hour high-quality service

User-friendly online submission system

Fair and swift peer-review system

Efficient typesetting and proofreading procedure

Display of the result of downloads and visits, as well as the number of cited articles

Maximum dissemination of your research work

Submit your manuscript at: http://papersubmission.scirp.org/

Or contact msce@scirp.org 